\title{
PRODUCTIVITY OF MECHANIZED WOOD ASH APPLICATION IN FOREST
}

\author{
Modris Okmanis, Guna Petaja, Ainārs Lupikis \\ Latvian State Forest Research Institute 'Silava' \\ modris.okmanis@silava.lv
}

\begin{abstract}
Importance of the study is determined by increasing consumption of woody biomass as a renewable energy source. Whole-tree harvesting is commonly applied for bioenergy use, however intensified biomass removal from forests can cause significant nutrient loss in soil. Nutrients can be returned to forest ecosystem by fertilizing soil with wood ash, which is generated as a by-product of combustion in wood-burning power plants and heating plants. Studies on ash spreading technological processes and costs so far have been insufficient. Aim of the study is to compare the productivity and prime cost of ash spreading with modular spreading trailer and Amazone mineral fertilizer spreader. According to study results productivity of modular trailer is $0.57 \mathrm{ha} \mathrm{h}^{-1}$ and the spreading costs are $88 \mathrm{EUR}^{-1} \mathrm{ha}^{-1}$, but that of mineral fertilizer spreader Amazone - $0.61 \mathrm{ha} \mathrm{h}^{-1}$ and $41 \mathrm{EUR} \mathrm{ha}^{-1}$, respectively. Despite lower productivity modular trailer is more suitable for spreading wood ash, because a larger amount can be delivered and ash is applied more evenly. Productivity of modular trailer can be increased by technical improvements, like equipping the tractor with a crane and a small excavator bucket. Comparing costs of ash spreading and deposition, additional 8.72 EUR $\mathrm{ha}^{-1}$ were required, when using modular trailer, whereas, when using mineral fertilizer spreader, $77.52 \mathrm{EUR}^{-1} \mathrm{can}^{-1}$ be saved. The main reason for the difference is smaller dosage when using modular spreader and additional loading costs.
\end{abstract}

Key words: forest fertilization, wood ash, productivity.

\section{Introduction}

Intensification of forestry, for example, wholetree harvesting method, which is getting more necessary because of increasing biofuel demand, can significantly increase nutrient loss in soil (Mälkönen, 1976). One of the unrated nutrient sources, which could be recovered back to forest ecosystems, is biomass ash that is left after biomass thermal processing. Biomass ash may consist of considerable amount of nutrients - Ca, P, K, Mg etc. (Misra, Ragland, \& Baker, 1993; James et al., 2012; Vassilev, Baxter, \& Vassileva, 2013; Okmanis, Lazdina, \& Lazdinš, 2015). In Latvia wood-based biomass is mostly used for heat and energy production. Studies show that wood-based biomass, comparing with other biomass forms, after combustion has relatively lower levels of indissoluble ash, which contains more compounds with low temperature melting point and causes slag, whereas the content of soluble - plant available nutrients is high (Hakkila, 1984; Nunes, Matias, \& Catalão, 2016) thus providing better results on tree growth response comparing, for example, to peat ash (Hytonen, 2003). Numerous studies have been made on forest fertilization with biomass based on ash and contradictory results are revealed. Neutral or even slightly negative effect on tree growth was found on mineral uplands fertilized with wood ash, but increase of needle nutrient content was still observed (Jacobson, 2003; Moilanen et al., 2013). However in Nordic countries significantly larger tree increments on ash-fertilized drained peatlands are found, where mostly $\mathrm{P}$ and $\mathrm{K}$ deficiency is observed (Moilanen, Silfverberg, \& Hokkanen, 2002; Sikström, Almqvist, \& Jansson, 2010; Ernfors et al.,
2010; Moilanen, Hytönen, \& Leppälä, 2012; Hökkä, Repola, \& Moilanen, 2012; Moilanen et al., 2013; Kikamägi, Ots, \& Kuznetsova, 2013). Wood ash is considered even better than the commercial fertilizers because of slower nutrient release. Moilanen (2015) concludes that wood ash fertilization is economically feasible and already during commercial thinning annual income was three times higher than in control (Moilanen et al., 2015). Studies in Latvia also reveal that ash fertilization on drained organic soil induced additional volume increment from 2 to almost $5 \mathrm{~m}^{3}$ ha ${ }^{-1}$ per year (Okmanis et al., 2016).

There is still insufficient research on ash spreading technological processes. Forest fertilization in Latvia is not common practice therefore fertilizer spreading productivity could not be implemented from agriculture because of various obstacles in forest. Aircraft is used over difficult terrain, where ground vehicles cannot operate effectively (Page \& Gustafson, 1969), although ground based forwarder is two to three times cheaper (Väätäinen et al., 2011). Best results of fertilization could be gathered at conifer stands at age of 20 to 50 years, when productivity is already highest (Lỉbiete, Jansons, \& Zālìtis, 2009) and first commercial thinning is done - strip roads remaining for technological process. Purchase of specific fertilization machinery could be very costly. Solution of this problem could be adjustment of tractors used for other operations, for example, soil preparation. This could solve another problem of seasonal exploitation of machinery - while it is impossible to proceed with the soil preparation when soil is frozen, although possibility of element leaching should be assessed during thaw. 
Although slightly negative impact of forest operation machinery on soil compaction and remaining trees has been already proven (Ampoorter et al., 2007; Horn et al., 2007; Petersons, Dreska, \& Saveljjevs, 2010; Modig et al., 2012; Prindulis, Lazdiňš, \& Kalēja, 2015), significant stand damages related to soil nutrition status have been observed in some cases of Norway spruce stands in Latvia (Lazdiņš, Miezīte, \& Bārdule, 2011; Klavina et al., 2016; Okmanis et al., 2016). By now ash use in forest fertilization and forest fertilization has not been practiced in Latvia, however by certain activities and changes in regulations it could be as possible as in Nordic countries, therefore studies of ash mechanized application are necessary. The aim of this study is to analyse productivity of ground based mechanized wood biomass ash spreading using fourwheel agricultural tractor combined with modular ash spreader and regular fertilizer spreader.

\section{Materials and Methods}

First experiment of ash spreading was held at the end of November 2014 with forest-adjusted four-wheel farm tractor Valtra 6350, which has $105 \mathrm{hp}$ engine output and was equipped with four-wheel modular ash spreader. The second experiment was made with a more powerful (170 hp) four-wheel farm tractor Valtra T191 equipped with Amazone three point hitch fertilizer spreader during October 2016. In both cases operators had no experience in forest fertilization. According to Table 1, using full bearing potential of modular ash spreader, total mass of equipment would be $16660 \mathrm{~kg}$ (considering that ash density on average is $1000 \mathrm{~kg} \mathrm{~m}^{-3}$ ), which is close to loaded medium forwarder that is often used in commercial thinning in Latvia. However, because of rut formation on trails, on average only 2 tonnes of wood ash were loaded in trailer. The full weight of Valtra T191 equipment was only $8250 \mathrm{~kg}$. First case machinery was also about 5 $\mathrm{m}$ longer and ground clearance was $160 \mathrm{~mm}$ lower, which could limit agility and affect productivity (Table 1).

In both cases treatment was carried out in stands, where first commercial thinning was done in recent years and every $20 \mathrm{~m}$ had remained the skid trails (strip roads) with laid forestry residues. Forest stands in first case were distributed in Joint Stock Company 'Latvia's State Forests' Viesite forest district. Experiment of wood ash spreading was made in four (two Hylocomiosa and two Oxalidosa turf. mel.) Norway spruce (Picea abies (L.) Karst.) stands from age of 43 to 48 years (Table 2). About half of each stand was treated and in total $20 \mathrm{t}$ of wood ash were spread on 10 ha (treatment dose 2 tonnes ha-1) forest land. In second case stands represent only drained soils, which are located in Jelgava, Jaunkalsnava and Smiltene and are managed by Forest research station agency. In second experiment also birch (Betula pendula Roth) stands were included. About half of total area (5 ha) was fertilized and 15 tonnes (dose 3 tonnes $\mathrm{ha}^{-1}$ ) of wood ash were spread with Amazon fertilizer spreader.

Weather during the first experiment was cloudy, but with insignificant precipitation, temperature varied from 0 to $-7^{\circ} \mathrm{C}$. During the second experiment sky was overcast, but no precipitation was observed and air temperature varied from +9 to $+14{ }^{\circ} \mathrm{C}$.

Wood ash was taken from wood pellet plant 'NewFuels' and from wood pellet plant 'Latgran' (both plants are operating furnaces with moving grates, both have $20 \mathrm{MW}$ capacity and burn only wood based biomass). Before transportation ash was poured with water and loaded into big-bags of $500 \mathrm{~kg}$ each. Properties of utilized ash are shown in Table 3, origin of samples is not provided in the table. In first case (Sample 1), when dose was 2 tonnes ha ${ }^{-1}$, only $10.2 \mathrm{~kg}$ of $\mathrm{P}$ on 1 ha forest area were brought, while

\section{Specifications of ash spreading machinery}

Table 1

\begin{tabular}{|l|l|l|}
\hline \multicolumn{1}{|c|}{ Parameter } & \multicolumn{1}{c|}{ Valtra 6350 equipment } & \multicolumn{1}{c|}{ Valtra T191 equipment } \\
\hline Tractor mass, $\mathrm{kg}$ & 4660 & $5950+1000$ (hitch) \\
\hline- length, $\mathrm{mm}$ & $4534+1000$ (hoist) & $5150+1000$ (hitch) \\
\hline$-\quad$ width, $\mathrm{mm}$ & 2280 & 2330 \\
\hline- height, $\mathrm{mm}$ & 2730 & 3400 \\
\hline$-\quad$ ground clearance, $\mathrm{mm}$ & 500 & 590 \\
\hline Spreader mass, $\mathrm{kg}$ & 4000 & 300 \\
\hline- length, $\mathrm{mm}$ & 6200 & 1420 \\
\hline- width, $\mathrm{mm}$ & 2600 & 2440 \\
\hline- ground clearance, $\mathrm{mm}$ & 440 & 600 \\
\hline- volume, $\mathrm{m}^{3}$ & 8 & 1 \\
\hline
\end{tabular}


Table 2

\section{Parameters of treated stands}

\begin{tabular}{|l|l|c|l|c|c|}
\hline \multicolumn{1}{|c|}{ Stand } & Forest type & Area, ha & \multicolumn{1}{c|}{ Species/age } & Basal area, $\mathrm{m}^{2} \mathrm{ha}^{-1}$ & Stock, $\mathrm{m}^{3} \mathrm{ha}^{-1}$ \\
\hline \multicolumn{6}{|c|}{ Valtra 6350} \\
\hline $1-1$ & Hylocomiosa. & 6.3 & Spruce/48 & 23 & 235 \\
\hline $1-2$ & Oxalidosa turf. mel. & 5.7 & Spruce/48 & 21 & 214 \\
\hline $1-3$ & Oxalidosa turf. mel. & 2.1 & Spruce/43 & 21 & 214 \\
\hline $1-4$ & Hylocomiosa. & 4.4 & Spruce/48 & 18 & 171 \\
\hline \multicolumn{7}{|c|}{ Valtra T191 } & 26 & 314 \\
\hline $2-1$ & Myrtillosa mel. & 4.8 & Spruce/45 & 23 & 243 \\
\hline $2-2$ & Oxalidosa turf. mel. & 0.9 & Spruce/46 & 19 & 182 \\
\hline $2-3$ & Myrtillosa mel. & 2.1 & Birch/29 & 14 & 121 \\
\hline $2-4$ & Myrtillosa turf. mel. & 2.1 & Birch/28 & & \\
\hline
\end{tabular}

Wood biomass ash properties

Table 3

\begin{tabular}{|c|c|c|}
\hline Parameter & Sample 1 & Sample 2 \\
\hline $\mathrm{pHCaCl}_{2}$ & 11.9 & 12.6 \\
\hline C $_{\text {carb., }} \mathrm{g} \mathrm{kg}^{-1}$ & 15.5 & 13.7 \\
\hline Corg., $\mathrm{g} \mathrm{kg}^{-1}$ & 19.7 & 9.1 \\
\hline Stot., $\mathrm{mg} \mathrm{kg}^{-1}$ & 16.6 & 37.7 \\
\hline $\mathrm{N}_{\text {tot., }}, \mathrm{g} \mathrm{kg}^{-1}$ & 0.2 & 0.1 \\
\hline $\mathrm{P}, \mathrm{g} \mathrm{kg}^{-1}$ & 5.1 & 11.6 \\
\hline \multicolumn{3}{|l|}{$\mathrm{HNO}_{3}$ extractable elements } \\
\hline $\mathrm{K}, \mathrm{g} \mathrm{kg}^{-1}$ & 16.3 & 35.6 \\
\hline $\mathrm{Ca}, \mathrm{g} \mathrm{kg}^{-1}$ & 101.7 & 167.4 \\
\hline $\mathrm{Mg}, \mathrm{g} \mathrm{kg}^{-1}$ & 16.7 & 32.1 \\
\hline $\mathrm{Mn}, \mathrm{g} \mathrm{kg}^{-1}$ & 1.3 & 3.0 \\
\hline $\mathrm{Fe}, \mathrm{g} \mathrm{kg}^{-1}$ & 4,1 & 6.5 \\
\hline $\mathrm{Cd}, \mathrm{mg} \mathrm{kg}^{-1}$ & 8,8 & 3.5 \\
\hline $\mathrm{Pb}, \mathrm{mg} \mathrm{kg}^{-1}$ & 77.4 & 104.7 \\
\hline $\mathrm{Cr}, \mathrm{mg} \mathrm{kg}^{-1}$ & 348.1 & 122.9 \\
\hline $\mathrm{Ni}, \mathrm{mg} \mathrm{kg}^{-1}$ & 24.5 & 27.5 \\
\hline $\mathrm{Cu}, \mathrm{mg} \mathrm{kg}^{-1}$ & 62.6 & 172.4 \\
\hline
\end{tabular}

in second case (Sample 2; 3 tonnes ha ${ }^{-1}$ of wood ash) dosage was $34.5 \mathrm{~kg} \mathrm{ha}^{-1}$. Amount of nutrients brought into forest in both cases differs significantly, referring to suggestion to determine ash chemical composition before using them as fertilizer.

Time for all work elements (wood ash loading, arriving from loading place to stand, wood ash spreading, driving out and also stump cutting) in total productive time consumption for each object was registered. Alternative income of ash utilization as fertilizer was calculated according to formula 1 :

$$
I=D W-\frac{S}{P}
$$

where

I - income of wood ash use in forest fertilization, EUR ha ${ }^{-1}$;

$\mathrm{D}$ - costs of waste deposition, EUR $\mathrm{t}^{-1}$;

$\mathrm{W}$ - wood ash dose, $\mathrm{t} \mathrm{ha}^{-1}$;

$\mathrm{S}$ - implement service cost of farm tractor, EUR $\mathrm{h}^{-1}$;

$\mathrm{P}$ - productivity of mechanized fertilization, ha $\mathrm{h}^{-1}$. 
Wood ash landfilling costs are 39.50 EUR t $^{-1}$ and 1 hour implement service of machinery costs are 25.00 EUR (average farm tractor rental cost including operator by the experiment time).

\section{Results and Discussion}

In first case 17.54 hours were spent for 10 ha fertilization and in second case 8.20 hours for 5 ha fertilization. So the average productivity of modular spreading trailer in ash spreading was 0.57 ha $\mathrm{h}^{-1}$, but that of Amazone mineral fertilizer spreader was $0.61 \mathrm{ha} \mathrm{h}^{-1}$. The result is two times lower than in Sweden and almost three times lower than in Finland, when forwarder with a centrifugal spreader was used (Emilsson, 2006; Vaatainen et al., 2007). When working with ash spreader, another tractor with front-end loader was used for ash loading, therefore 2 technical units were included in costs. Under conditions of production, the second tractor had to be replaced with crane, which was mounted onto 3-point-hitch. Installation of crane would reduce ash spreading costs. When working with mineral fertilizer spreader Amazone, ash was loaded with a lifting device strengthened for the spreader, which has a limited functionality and it is reflected in working time consumption. One of solutions is strengthening the lifting device and equipping with electric winch to pull in ash bags. Mineral fertilizer spreaders are adjusted for spreading pre-packed material, which impose additional restrictions.

When comparing both technical solutions for ash spreading, a range of factors should be considered - distance from ash loading site to the stand, stand configuration, soil bearing capacity etc. Amazone mineral fertilizer spreader is intended for spreading granulated and free-flowing material, therefore during trials feeder had to be cleaned regularly and ash had to be mixed in order not to adhere to sides and sieve. Modular spreader is suitable for spreading unscreened, non-granulated, heterogeneous wood ash. Both devices have a problem with material freezing at sides when spreading wetted ash in cold weather, therefore recommendations prepared in this research include a suggestion to change metal plates for plywood. None of devices can spread dry ash with a significant proportion of light fraction. Ash processing with self-hardening, pelletizing or granulation technology is an obligatory requirement for ash application in forest.

Differences in work productivity are caused by technical gauges and ability to manoeuvre as well. When spreading ash with modular trailer, most time $(48 \%)$ is consumed by driving into the stand (Figure 1) as gauges of tractor and trailer are unsuitable for driving in a roundabout way in thinning technological corridors. Operator had to drive into the stand in reverse motion (with a trailer in front), in order to spread ash by pulling the trailer. Tractor used for this trial was too light to drive a loaded trailer (6-8 tonnes, depending on load weight and moisture content in ash), therefore even small inclines could cause towing. In practice, when using a tractor with suitable size (unloaded weight at least 7 tonnes), work productivity would significantly increase. An alternative solution is mounting the current ash spreading device to the frame of a forwarder (LSFRI Silava has started working on adapting ash spreader for Vimek 610 and Vimek 610 BioCombi forwarders) or equipping rear tandem with hydraulic drive. As a result of the research, ash spreader has already been reconstructed, lifting higher the spreading mechanism and shortening frame length.

When spreading ash with mineral fertilizer spreader, only $13 \%$ of total working time was consumed by driving into the stand (Figure 2), because device's ability to manoeuvre was not limited and towing risk was relatively low. At the same time in first case $42 \%$ of all time was spent on reaching the stand. Opposite situation was observed with loading - much less time was spent in first case, when additional tractor with wheel loader was used. Clearance of modular spreaders is lower than that of

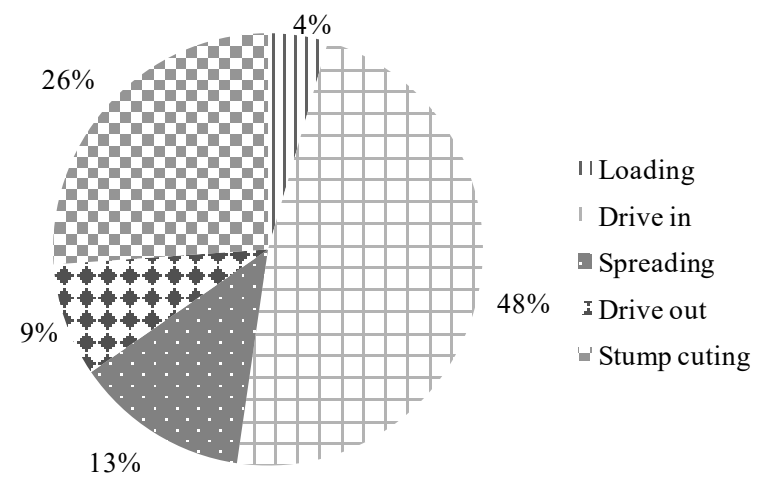

Figure 1. Working time distribution of wood ash spreading with modular trailer. 


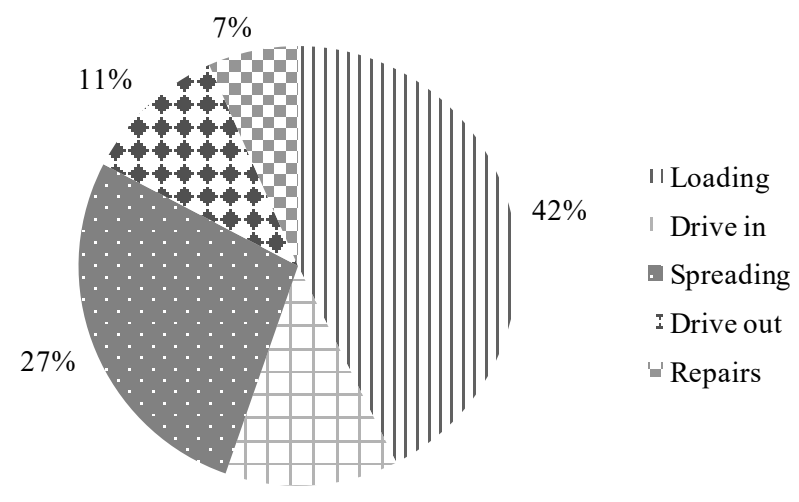

$13 \%$

Figure 2. Working time distribution of ash spreading with mineral fertilizer spreader Amazone.

Amazone spreader, therefore, when working with ash spreading trailer, $26 \%$ of the total time was consumed by cutting higher stumps in order to protect spreading mechanism and hydraulic engine from possible damages. Observations on time consumption suggest that better technical solution should be developed by combining qualities of both machineries.

Productivity would significantly increase if spreading mechanism was lifted at one level with the trailer frame and installation of additional protection, because stump cutting is no longer required. Movement time would be shortened as well, because trailer is shorter by half a meter.

Amazone mineral fertilizer spreader is suitable for spreading granulated ash, which has to be pre-packed in bags with a maximum weight of $500 \mathrm{~kg}$. This method has advantages if ash is timely delivered to the stand and spreader is not tied to ash delivery. Granulated ash, which is pre-packed in bags, can be stored in application site without a risk of getting soaked by the rain. Small volumes of bags enable precision of ash doses for each stand and tractor driving time is shortened significantly when delivering ash to each stand. These advantages can be used when working with ash spreader trailer. Ash bag size is limited by the power of installed crane.

Ash spreading costs, excluding load size and time consumed by loading, unloading and driving, are determined by technological corridor location in the stand - total driving distance in the stand and average driving speed. Productivity and costs of wood ash spreading can be easily modelled.

Ash spreading costs in trial with modular trailer were 43.86 EUR ha ${ }^{-1}$, but with mineral fertilizer spreader - 40.98 EUR ha $^{-1}$, excluding service of frontal lifting device. Approximate ash deposit costs are 39.5 EUR t ${ }^{-1}$. Since in the second scenario (Valtra $6350+$ Amazone) 3 tonnes of wood ash per hectare were spread, alternative income of ash spreading in forest, instead of deposition, is 77.52 EUR ha'. ${ }^{-1}$ When using modular ash spreader frontal loader service was included - total costs $87.72 \mathrm{EUR}^{-1} \mathrm{ha}^{-1}$ and only $2 \mathrm{t} \mathrm{ha}^{-1}$ of ash were spread, as a result additional 8.7 EUR ha-1 should be paid for ash spreading. Wood ash spreading costs with modular trailer can be reduced by installing crane on the tractor. Reduction of costs can be achieved by increasing ash dosage by amount, which ensures optimal addition of nutrients. In trials with modular trailer, in order to apply sufficient amount of potassium and phosphorus to the soil, ash dosage must be increased by up to $5 \mathrm{t} \mathrm{ha}^{-1}$. In this case, reduction of costs would be greater, of course ash spreading productivity would also change by changing dosage.

Unprocessed ash was used in trials, therefore in practice ash hardening, crushing and quality control will cause additional costs. However increased tree growth is expected and with sufficient information about additional increments IRR (internal rate of return) could be calculated.

\section{Conclusions}

1. When working with modular trailer, ash spreading productivity is 0.57 ha $^{-1}$, but with mineral fertilizer spreader $-0.61 \mathrm{ha} \mathrm{h}^{-1}$.

2. When using modular spreading trailer and additional tractor with frontal loader for ash loading, ash spreading costs are 87.72 EUR ha', but when using Amazone spreader with hydraulic lifting device $-40.98 \mathrm{EUR}^{\mathrm{h}} \mathrm{H}^{-1}$.

3. Comparing ash spreading costs with expenditure for its deposition, in the first trial, when ash was spread in the forest using modular trailer, additional 8.72 EUR ha-1 were required, but in the second trial, when using mineral fertilizer spreader, 77.52 EUR ha $^{-1}$ could be saved.

\section{Acknowledgements}

The experiment was established within the scope of the Forest sector competence center No. 1.2.1.1/16/A/009 "Methods for planning and quality assurance of forest fertilization measures". 


\section{References}

1. Ampoorter, E., Goris, R., Cornelis, W.M., \& Verheyen, K. (2007). Impact of mechanized logging on compaction status of sandy forest soils. Forest Ecology and Management, 241 (1-3), 162 - 174. DOI: 10.1016/j.foreco.2007.01.019.

2. Emilsson, S. (2006). From extraction of forest fuels to ash recycling (400 ex). Jönköping, Sweden: Swedish forest agency.

3. Ernfors, M., Sikström, U., Nilsson, M., \& Klemedtsson, L. (2010). Effects of wood ash fertilization on forest floor greenhouse gas emissions and tree growth in nutrient poor drained peatland forests. Science of The Total Environment, 408(20), 4580 - 4590. DOI: 10.1016/j.scitotenv.2010.06.024.

4. Hakkila, P. (1984). Forest chips as fuel for heating plants in Finland. Folia Forestalia, 586, 1 - 62.

5. Hökkä, H., Repola, J., \& Moilanen, M. (2012). Modelling volume growth response of young Scots pine (Pinus sylvetris) stands to N, P, and K fertilization in drained peatland sites in Finland. Canadian Journal of Forest Research, 42(7), 1359 - 1370. DOI: 10.1139/x2012-086.

6. Horn, R., Vossbrink, J., Peth, S., \& Becker, S. (2007). Impact of modern forest vehicles on soil physical properties. Forest Ecology and Management, $248(1-2), 56$ - 63. DOI: 10.1016/j. foreco.2007.02.037.

7. Hytonen, J. (2003). Effects of wood, peat and coal ash fertilization on Scots pine foliar nutrient concentrations and growth on afforested former agricultural peat soils. Silva Fennica, 37 (2), $219-234$.

8. Jacobson, S. (2003). Addition of stabilized wood ashes to Swedish coniferous stands on mineral soilseffects on stem growth and needle nutrient concentrations. Silva Fennica, 37 (4), $437-450$.

9. James, A., Thring, R., Helle, S., \& Ghuman, H. (2012). Ash Management Review-Applications of Biomass Bottom Ash. Energies, 5(12), 3856 - 3873. DOI: 10.3390/en5103856.

10. Kikamägi, K., Ots, K., \& Kuznetsova, T. (2013). Effect of wood ash on the biomass production and nutrient status of young silver birch (Betula pendula Roth) trees on cutaway peatlands in Estonia. Ecological Engineering, 58, 17 - 25. DOI: 10.1016/j.ecoleng.2013.06.014.

11. Klavina, D., Menkis, A., Gaitnieks, T., Velmala, S., Lazdins, A., Rajala, T., \& Pennanen, T. (2016). Analysis of Norway spruce dieback phenomenon in Latvia - a belowground perspective. Scandinavian Journal of Forest Research, 31 (2), 156 - 165. DOI: 10.1080/02827581.2015.1069390.

12. Lazdiṇš, A., Miezīte, O., \& Bārdule, A. (2011). Characterization of severe damages of spruce (Picea abies (L.) H.Karst.) stands in relation to soil properties. In Annual 17th internacional scientific conference proceedings Research for rural developmentResearch (pp. 22 - 29). Jelgava: LLU.

13. Lībiete, Z., Jansons, J., \& Zālītis, T. (2009). Age structure and productivity of conifer stands in Latvia. Mežzinātne/Forest Science, 19 (52), 28 - 48.

14. Mälkönen, E. (1976). Effect of whole-tree harvesting on soil fertility. Silva Fennica, 10 (3), $157-164$.

15. Misra, M.K., Ragland, K.W., \& Baker, A.J. (1993). Wood ash composition as a function of furnace temperature. Biomass and Bioenergy, 4 (2), 103 - 116. DOI: 10.1016/0961-9534(93)90032-Y.

16. Modig, E., Magnusson, B., Valinger, E., Cedergren, J., \& Lundqvist, L. (2012). Damage to residual stand caused by mechanized selection harvest in uneven-aged Picea abies dominated stands. Silva Fennica, 46 (2), $267-274$.

17. Moilanen, M., Hytönen, J., Hökkä, H., \& Ahtikoski, A. (2015). Fertilization increased growth of Scots pine and financial performance of forest management in a drained peatland in Finland. Silva Fennica, 49 (3). DOI: $10.14214 /$ sf.1301.

18. Moilanen, M., Hytönen, J., \& Leppälä, M. (2012). Application of wood ash accelerates soil respiration and tree growth on drained peatland. European Journal of Soil Science, 63 (4), 467 - 475. DOI: 10.1111/j.13652389.2012.01467.x.

19. Moilanen, M., Saarsalmi, A., Kukkola, M., \& Issakainen, J. (2013). Effects of stabilized wood ash on nutrient status and growth of Scots pine - Comparison between uplands and peatlands. Forest Ecology and Management, 295, 136 - 144. DOI: 10.1016/j.foreco.2013.01.021.

20. Moilanen, M., Silfverberg, K., \& Hokkanen, T.J. (2002). Effects of wood-ash on the tree growth, vegetation and substrate quality of a drained mire: a case study. Forest Ecology and Management, 171 (3), $321-338$.

21. Nunes, L.J.R., Matias, J.C.O., \& Catalão, J.P.S. (2016). Biomass combustion systems: A review on the physical and chemical properties of the ashes. Renewable and Sustainable Energy Reviews, 53, $235-242$. DOI: 10.1016/j.rser.2015.08.053.

22. Okmanis, M., Lazdiņa, D., \& Lazdiņš, A. (2015). The Composition and Use Value of Tree Biomass Ash. Rural Sustainability Research, 34 (329). DOI: 10.1515/plua-2015-0011. 
23. Okmanis, M., Skranda, I., Lazdiňš, A., \& Lazdina, D. (2016). Impact of wood ash and potassium sulphate fertilization on growth of Norway spruce stand on organic soil. In Annual 22nd International Scientific Conference Proceedings, "Research for Rural Development" (Vol. 2, pp. 62 - 68). Jelgava: LLU.

24. Page, J.M., \& Gustafson, M.L. (1969). Equipment for Forest Fertilization. In SAE Technical Paper. SAE International. DOI: 10.4271/690553.

25. Petersons, J., Dreska, A., \& Saveljevs, A. (2010). Assessing reach of the stems to be removed and the quality of remaining stand in machined thinnings. Mežzinātne/Forest Science, 22(55), 116 - 128.

26. Prindulis, U., Lazdiņ̌s, A., \& Kalēja, S. (2015). Impact of biomass extraction method on damage to remaining trees in mechanized thinning of deciduous stands. In Annual 21th International Scientific Conference Proceedings, 'Research for Rural Development' (pp. 74 - 80). Jelgava: LLU.

27. Sikström, U., Almqvist, C., \& Jansson, G. (2010). Growth of Pinus sylvestris after the Application of Wood Ash or P and K Fertilizer to a Peatland in Southern Sweden. Silva Fennica, 44(3), 411 - 425.

28. Väätäinen, K., Sirparanta, E., Räisänen, M., \& Tahvanainen, T. (2011). The costs and profitability of using granulated wood ash as a forest fertilizer in drained peatland forests. Biomass and Bioenergy, 35(8), 3335 - 3341. DOI: 10.1016/j.biombioe.2010.09.006.

29. Vaatainen, K., Tahvanainen, T., Sirparanta, E., \& Lamminen, S. (2007). Energy wood from early thinnings (Project report No. EIE/04/086/S07.38582) (p. 30). Finnish Forest Research Institute. Retrieved February 15, 2017, from: https://ec.europa.eu/energy/intelligent/projects/sites/ieeprojects/files/projects/ documents/5_eures_energy_wood_from_early thinnings.pdf.

30. Vassilev, S.V., Baxter, D., \& Vassileva, C.G. (2013). An overview of the behaviour of biomass during combustion: Part I. Phase-mineral transformations of organic and inorganic matter. Fuel, 112, $391-449$. DOI: 10.1016/j.fuel.2013.05.043. 